\title{
Effects of fish stocking density on growth and survival of Silver carp (Hypophthalmichthys molitrix) fry in Jashore, Bangladesh
}

\author{
SK INJAMAMUL ISLAM, HASAN MAHMUD NOOR, MD. HABIBUR RAHMAN, \\ MD. SAROWER-E-MAHFUJ, SYEDA MAKSUDA YEASMIN AND \\ MD. ANISUR RAHMAN* \\ Department of Fisheries and Marine Bioscience \\ Jashore University of Science and Technology, Jashore 7408, Bangladesh \\ "Corresponding Author: anis.fmb@just.edu.bd
}

\begin{abstract}
The experiment was operated in 9 consecutive weeks in nine earthen nursery ponds having the same area (0.09 acre) and depth $(0.8 \mathrm{~m})$. Seven days old fries of Silver carp (Hypophthalmichthys molitrix) were stocked at 4000, 5000 and 6000 fries/decimal in three treatments with three replications as T-1, T-2 and $\mathrm{T}-3$, respectively to observe the growth and survival. At stocking, hatchlings were the same batch-rearing with an average length and weight of $0.44 \pm 0.05 \mathrm{~cm}$ and $0.14 \pm 0.05 \mathrm{mg}$, respectively. Wet mustered oil cake and commercial nursery feed containing $30 \%$ crude protein were given by two weeks interval, initially according to the bodyweight; the feeding rate was $14 \%$ in the first two weeks, gradually reduced to 12,10 and $8 \%$, respectively in the following week intervals. Water quality parameters and plankton sufficiency were observed every 15 days interval and was found within the acceptable range. Growth performance $(6.458 \mathrm{~g})$, survival rate of fingerlings $(85.76 \%)$ and total production $(22151 \mathrm{~g} / \mathrm{decimal})$ were found highest in $\mathrm{T}-1$ followed by T-2 and T-3. The study concluded that expect better production of fry up to fingerlings, proper stocking density should be maintained in pond fish culture in Jashore region of Bangladesh.
\end{abstract}

Keywords: Silver carp, Hypophthalmichthys molitrix, Stocking density

\section{Introduction}

Hypophthalmichthys molitrix commonly known as Silver carp, is a large cyprinids, native to China and are considered permissible invasive species in North America (Stepien et al. 2019). Compared to other carp species, Silver carp is frequently used in polyculture systems in Bangladesh (Hossain et al. 2013). It is by and large thought to be a planktivorous fish (Anderson et al. 2016). Planktivorous Silver carp and Pangasiid catfish together in a polyculture system can make better the pond water parameter by skimming the phytoplankton by the second species and enhance the growth rate of past species (Ferdousi and Haque 2006). Population density of fish is an imperative factor influencing the growth rate and development of wild and farmed fish species alongside food supply and its hereditary qualities, and natural conditions (Malik et al. 2014). Survival rate, growth, behavior, health, feeding habit and production of fishes were influenced by water quality and stocking density (Huang et al. 2008). In pond environment, fry and fingerlings growth rate along with survival rate largely rely upon the stocking density, type and nature of manure applied to the pond and supplementary feed given to fish species (Rahman et al. 2009). Higher stocking density of a species may affect the growth of other species; conversely, lower density of a species may reduce the overall production (Apu et al. 2012, Rahman and Marimuthu 2010). The majority of the fish farmers of Bangladesh projected that higher stocking density gives them better outcome. So, they culture fish fingerlings or fry in extremely high density which causes uncertainty and irregularities in the pond water qualities including instance fluctuation in $\mathrm{pH}$, temperature, and ammonia (Shoko et al. 2014). However,

https://doi.org/10.52168/bjf.2021.33.08 
farmers may dishearten if the low stocking density is non-profitable to them. Previously, few studies were conducted on population densities of fishes like Climbing perch, Tilapia, and Bata, except silver carp. There is a lack of research on the effects of stocking density on Silver carp especially in Jashore district, Bangladesh. In this regard, the objective of the study was to comprehend and assess the reasonable stocking density for $H$. molitrix for aquaculture, keeping in mind the survival, growth rate, and production of fry in the nursery ponds.

\section{Materials and Methods}

Study area and period: This experiment was conducted for the period of three months (AprilJune, 2020) at Satata fish nursery complex (a non-government fish nursery), located at Chanchra, in Jashore district $\left(23.1634^{\circ} \mathrm{N}, 89.2182^{\circ} \mathrm{E}\right)$, Bangladesh.

Experimental design: To understand the growth performance of Silver carp along with survival rate in nursery phase, 3 distinct treatments (T-1, 4000 fries/decimal with 3 replicates; T-2, 5000 fries/decimal with 3 replicates and T-3, 6000 fries/decimal with 3 replicates) were conducted.

Pond preparation and fry sampling: The pond was dewatered and lime was applied lime over the pond bottom 2-3 times in a single year at the rate of 1000-1200 g/decimal. The pond was fertilized by applying Triple super phosphate (TSP), urea and murate of potash (MoP) at a rate of $170 \mathrm{~g}, 100 \mathrm{~g}$ and $75 \mathrm{~g} /$ decimal respectively. Sampling was done by applying a mash net to detect the growth rate of Silver carp fries at 15 days interval. The growth rate of the fry was calculated by using a digital electronic balance. Pond conditions and fry's health status were monitored consistently during the culture period. The sampled Silver carp fries were handled cautiously as the species are truly vulnerable to dealing with stress.

Feeding and feed composition: At the beginning, formulated feed (Nourish nursery feed) was supplied two times daily (morning and afternoon) at a ratio of $14 \%$ of their body weight. Mainly wetting mustard oil cake was used for the feeding to fingerlings. The proximate composition (\% dry matter basis) was used in the experiment as follows: carbohydrate $60 \%$, protein $30 \%$, lipid $4 \%$, ash $2 \%$, crude fiber $2 \%$ and nitrogen free extract (NFE) $2 \%$.

Estimation of water quality parameters: With the help of thermometer graduated in centigrade scale water temperature was recorded on spot (YSI, model 58). A multimeter used to measure dissolved oxygen (DO) in $\mathrm{mg} / \mathrm{L}$. HACH Sension $\mathrm{pH} 1$ multimeter was used to record the $\mathrm{pH}$. Alkalinity of the pond water was measured in $\mathrm{mg} / \mathrm{L}$ with the help of an alkalinity test Hachkit (FF- 1A).

Growth measurement: The growth of silver carp fries was monitored at 15 days interval from each pond through random sampling with the help of a warp mash net to assure their complete body weight and length. Following formulas were used for the estimation of growth parameters: Weight gain (g): Weight gain $(\mathrm{g})=$ Mean final weight $(\mathrm{g})$ - Mean initial weight (g)

(\%) Percent of weight gain: This is straight forward measure of the overall increase in mean body weight over a period.

\% Weight gain $=\frac{\text { Mean final fish weight }- \text { Mean initial fish weight }}{\text { Mean initial fish weight }} \times 100$ 
Specific growth rate (SGR) (\% per day):

SGR $(\%$ per day $)=\frac{\log W 2-\log W 1}{T 2-T 1} \times 100$

Where, $\mathrm{W} 1=$ the initial live body weight $(\mathrm{g})$ at time $\mathrm{T} 1$ (day), $\mathrm{W} 2=$ the final live body weight

(g) at time $\mathrm{T} 2$ (day), $\mathrm{T} 2=$ time at the end of the experiment, $\mathrm{T} 1=$ time at the initial of the

experiment

Survival rate (\%): It was calculated as:

Survival rate $(\%)=\frac{\text { No. of fish harvested }}{\text { No. of fish stocked }} \times 100$

Data analysis: An ANOVA was used to decide the impact of water quality and diverse performance of the growth of silver carp. Data were analyzed by using the SPSS programming (Statistical Package for Social Science) version 20 as per Duncan's New Multiple Range test to distinguish the $5 \%$ degree of significance of difference among the distinctive treatment implies.

\section{Results}

Water quality parameters: Water quality parameters such as temperature $\left({ }^{\circ} \mathrm{C}\right), \mathrm{pH}$, dissolved oxygen $(\mathrm{mg} / \mathrm{L})$, and total alkalinity $(\mathrm{mg} / \mathrm{L})$ were recorded 15 days interval. One-way analysis of variance (ANOVA) was performed to measure whether any difference exists in the mean values of water quality parameters among different treatments (Table I).

Table I. Difference in the water quality parameters of three individual treatments pond

\begin{tabular}{llll}
\hline Parameters & \multicolumn{3}{c}{ Treatments } \\
\cline { 2 - 4 } & T-1 $( \pm \mathrm{SD})$ & $\mathrm{T}-2( \pm \mathrm{SD})$ & $\mathrm{T}-3( \pm \mathrm{SD})$ \\
\hline Temperature $\left({ }^{\circ} \mathrm{C}\right)$ & $30.28 \pm 1.169$ & $30.72 \pm 1.003$ & $30.09 \pm 1.205$ \\
Transparency $(\mathrm{cm})$ & $31.62 \pm 2.760$ & $31.08 \pm 2.203$ & $29.43 \pm 2.562$ \\
$\mathrm{pH}$ & $8.03 \pm 0.110$ & $8.06 \pm 0.111$ & $7.97 \pm 0.132$ \\
$\mathrm{DO}(\mathrm{mg} / \mathrm{L})$ & $5.55 \pm 0.342$ & $5.16 \pm 0.156$ & $5.017 \pm 0.108$ \\
\hline
\end{tabular}

Temperature $\left({ }^{\circ} \mathrm{C}\right)$ : The water temperature of experimental ponds was found to vary from 28.9 to $31.7,29.2$ to 31.01 and 28.7 to $31.84^{\circ} \mathrm{C}$ with the mean $( \pm \mathrm{SD})$ values of $30.28 \pm 1.169$, $30.72 \pm 1.037$ and $30.09 \pm 1.20{ }^{\circ} \mathrm{C}$ in $\mathrm{T}-1, \mathrm{~T}-2$ and $\mathrm{T}-3$, respectively. There was no significant difference $(p<0.05)$ among three treatments, when statistical analysis performed (Fig. I). 


\section{EFFECTS OF FISH STOCKING DENSITY ON GROWTH AND SURVIVAL OF H. MOLITRIX FRY}

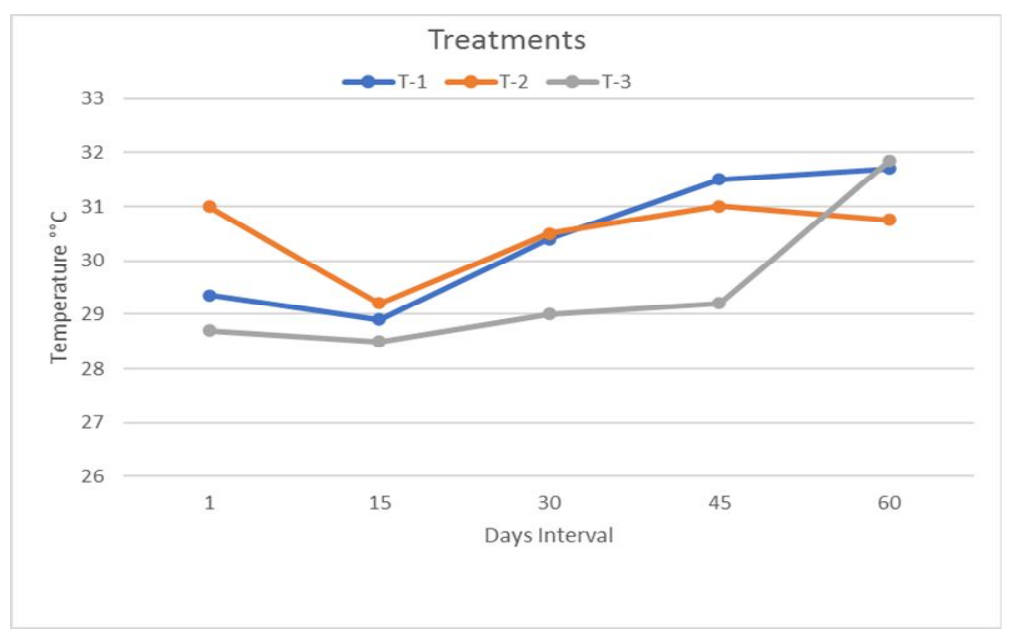

Fig. 1. Variation of temperature among three treatments after 15 days interval.

Transparency: Water transparency varied in different ponds under different treatments. Transparency was found to vary from 27.10 to $34.16,28.77$ to 34.46 and 27.50 to $31.75 \mathrm{~cm}$ with the mean $( \pm \mathrm{SD})$ values of transparency were $31.62 \pm 2.760 \quad 31.08 \pm 2.203$ and $29.43 \pm 2.562 \mathrm{~cm}$ in T-1, T-2 and T-3, respectively. The statistical analysis showed that the values are not significantly different $(p<0.05)$ (Fig. 2).

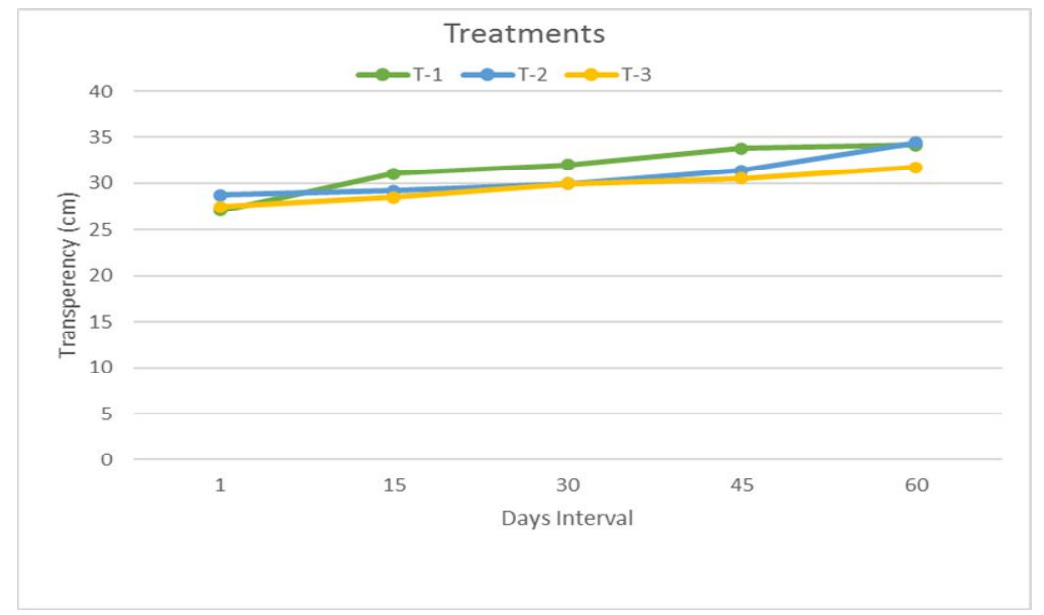

Fig. 2. Variation of transparency among three treatments after 15 days interval.

pH (Hydrogen ion concentration): $\mathrm{pH}$ was found to fluctuate from 7.90 to $8.18,7.49$ to 8.54 and 7.89 to 8.13 during the experiment with the mean values of $\mathrm{pH}$ were $8.03 \pm 0.1109$, $8.006 \pm 0.1104$ and $7.987 \pm 0.131$ in $\mathrm{T}-1, \mathrm{~T}-2$ and T-3, respectively. There was no significant difference $(p<0.05)$ among three treatments in statistical analysis (Fig. 3). 


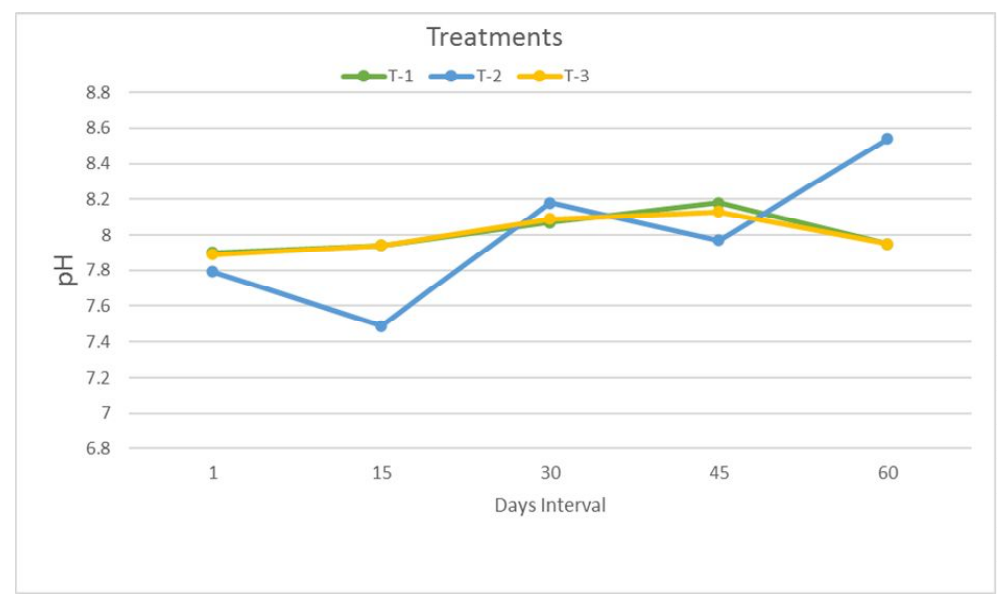

Fig. 3. Variation of $\mathrm{pH}$ among three treatments after 15 days interval.

Dissolved oxygen: DO concentration was found to vary from 5.13 to $6.01,5.01$ to 5.39 and 4.92 to $5.16 \mathrm{mg} / \mathrm{L}$ with the mean values of $5.55 \pm 0.342,5.162 \pm 0.156$ and $5.017 \pm 0.108 \mathrm{mg} / \mathrm{L}$ in T-1, T-2 and T-3, respectively. There was no significant difference $(p<0.05)$ among the dissolved oxygen values of T-1, T-2 and T-3, respectively (Fig. 4).

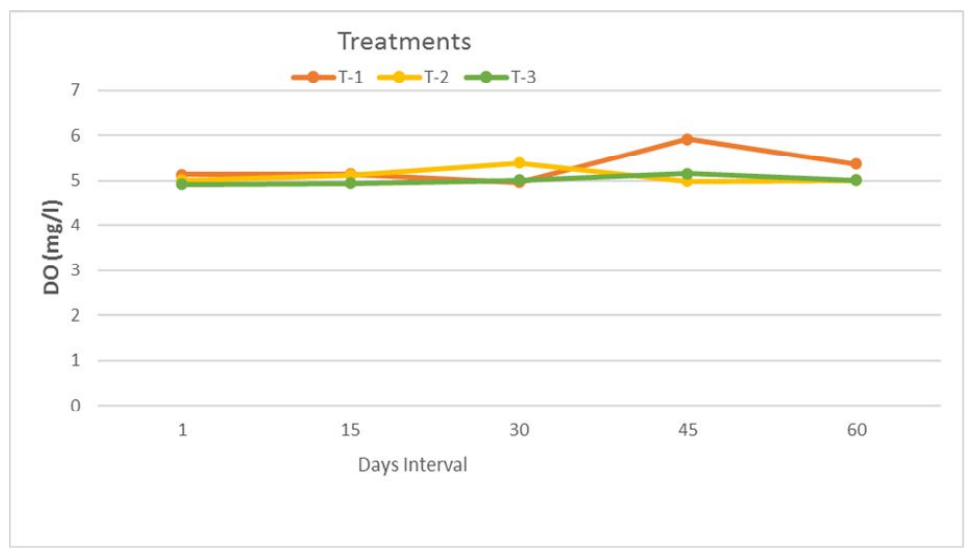

Fig. 4. Variation of DO among three treatments after 15 days interval.

Total alkalinity: Total alkalinity was found to vary from 152.78 to $158.34,150.83$ to 158.89 and 151.13 to $157.42 \mathrm{mg} / \mathrm{L}$. with the mean $( \pm \mathrm{SD})$ values of total alkalinity were $155.78 \pm 2.518,154.89 \pm 3.09$ and $154.65 \pm 2.667 \mathrm{mg} / \mathrm{L}$ in T-1, T-2 and T-3, respectively. The statistical analysis showed that there was no significant difference $(p<0.05)$ among three treatments (Fig. 5). 


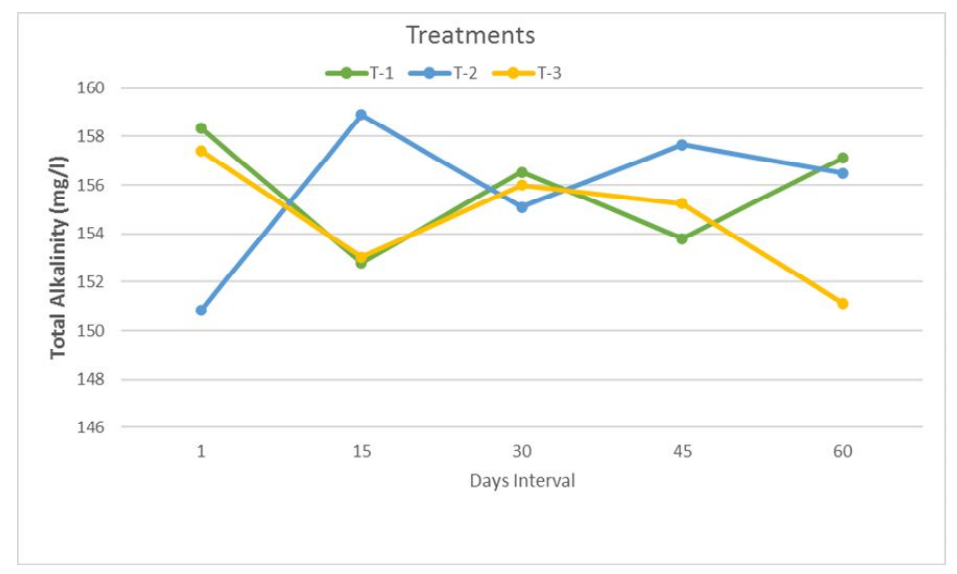

Fig. 5. Variation of total alkalinity among three treatments after 15 days interval.

Growth performance of silver carp fry: At the primary stage, the mean initial length of silver carp fries were $1.012 \pm 0.0526,1.012 \pm 0.0526$ and $1.012 \pm 0.0526 \mathrm{~cm}$ and initial weight of silver carp fries were $0.0016 \pm .00008,0.0016 \pm 0.00008$ and $0.0016 \pm 0.00008 \mathrm{~g}$ in T-1, T-2 and T-3 treatments respectively. Finally the study found that the mean final length of silver car fries were $5.780 \pm 0.129,5.165 \pm 0.182$ and $4.722 \pm 0.362 \mathrm{~cm}$ and mean final weight of silver carp fries $6.543 \pm 1.08,4.416 \pm 0.755$ and $3.165 \pm 0.873 \mathrm{~g}$ in $\mathrm{T}-1, \mathrm{~T}-2$, and $\mathrm{T}-3$ treatments, respectively. In T-1, T-2, and T-3 the mean weight gain found with mean value of $6.458 \pm 0.955,4.414 \pm 0.656$ and $3.163 \pm 0.773 \mathrm{~g}$, respectively. There was significant difference $(P<0.05)$ in initial weight of silver carp at different treatments (Table II). Among the treatments the difference of the mean final weight and mean weight gains of silver carp at different stocking densities were highly significant $(p<0.05)$ from each other (Table II). The mean specific growth rates were $14.13 \pm 3.13 \%, 13.29 \pm 2.04 \%, 12.64 \pm 2.49 \%$ respectively in T-1, T-2 and T-3 treatments. The highest value was obtained from $\mathrm{T}-1$ and the lowest value was obtained from $\mathrm{T}$ 3 . There was significance difference $(p<0.05)$ in specific growth rates of silver carp fries among different treatments. After 60 days of experimental period, the survival rate (\%) was calculated by pot system of $H$. molitrix from each of the experimental pond separately. The mean survival rates were found at $85.76 \pm 4.017,79.11 \pm 3.830,74.16 \pm 4.904 \mathrm{in} \mathrm{T}-1, \mathrm{~T}-2$, and $\mathrm{T}-3$ respectively. The highest value was obtained from T-1 and the lowest value was obtained from T-3. There was significant difference $(p<0.05)$ in survival rates of silver carp fries among the treatments.

Table II. Growth performances of silver carp fries in different stocking densities (Mean \pm SD)

\begin{tabular}{l|c|c|c|c}
\hline \multirow{2}{*}{ Characters } & \multicolumn{3}{|c|}{ Treatments } & \multirow{2}{*}{$\begin{array}{c}\text { Level of } \\
\text { significance }\end{array}$} \\
\cline { 2 - 4 } & $\mathrm{T}-1( \pm \mathrm{SD})$ & $\mathrm{T}-2( \pm \mathrm{SD})$ & $\mathrm{T}-3( \pm \mathrm{SD})$ & \multirow{2}{*}{ NS } \\
\hline Mean initial weight $(\mathrm{g})$ & $0.0016 \pm .00008$ & $0.0016 \pm .00008$ & $0.0016 \pm 0.000$ & $*$ \\
\hline Mean final weight $(\mathrm{g})$ & $6.543 \pm 1.08$ & $4.416 \pm 0.750$ & $3.165 \pm 0.870$ & $*$ \\
\hline Mean weight gain $(\mathrm{g})$ & $6.458 \pm 0.955$ & $4.414 \pm 0.656$ & $3.163 \pm 0.773$ & $*$ \\
\hline SGR $(\%$ body weight) & $14.13 \pm 3.13$ & $13.29 \pm 2.040$ & $12.64 \pm 2.49$ & $*$ \\
\hline Survival rate (\%) & $85.76 \pm 4.017$ & $79.11 \pm 3.830$ & $74.16 \pm 4.904$ & $*$ \\
\hline
\end{tabular}




\section{Discussion}

Water quality parameters: Aquatic environment is largely depending on temperature for ensuring survival allocation and conventional metabolism of fish the blood to adjust to temperature unsteadiness results in fish mortality (Enders and Boisclair, 2016; Neubauer and Andersen, 2019). In the present study, the minimum temperature $\left(30.09^{\circ} \mathrm{C}\right)$ was noticed in treatment T-3 and the maximum temperature $\left(30.72^{\circ} \mathrm{C}\right)$ was found in treatment $\mathrm{T}-2$ almost similar the revealed of (Kohinoor et al. 2018). Priyadarshini et al. (2011) recorded almost similar temperature values of pond water in carp rearing pond. Water transparency and phytoplankton biomass in a pond has opposite relationship (Attayde and Menezes 2008). Transparency reading is about 20 to $30 \mathrm{~cm}$ indicates that water body is productive (Gómez et al. 2009). During the study period, water transparency ranged from 27.10 to $34.46 \mathrm{~cm}$ which was relatively alike to the findings of (Kohinoor et al. 1994, Rahman 2015). In the experimental area appropriate liming was done in ponds to neutralize $\mathrm{pH}$ level. Therefore, this is not only to keep the water $\mathrm{pH}$ neutral but also increase the productivity. $\mathrm{pH}$ value found $8.03 \pm 0.110$, $8.06 \pm 0.111$ and $7.97 \pm 0.132$ in treatments $\mathrm{T}-1, \mathrm{~T}-2$, and T-3 reciprocally during the study period. Researchers found the $\mathrm{pH}$ value between $6.64 \pm 0.95$ to $8.32 \pm 0.75(\mathrm{mg} / \mathrm{l})$ in their research (Chakraborty and Mirza 2007, Hossain 2014, Kohinoor et al. 1994, Priyadarshini et al. 2011). Some studies stated that dissolved oxygen concentration is getting higher in winter season and lower in summer season (Badran 2001, Rounds et al. 2006, Xu et al. 2016). The minimum Dissolved oxygen level observed in the present study was $5.017 \pm 0.108 \mathrm{mg} / \mathrm{l}$ in $\mathrm{T}-3$ and maximum was $5.55 \pm 0.342 \mathrm{mg} /$ in T-1 that agrees well with the findings of (Boyd 2003). The mean values of total alkalinity were found $155.78 \pm 2.518,154.89 \pm 3.091$ and $154.64 \pm 2.677$ $\mathrm{mg} / \mathrm{l}$ in T-1, T-2, and T-3, respectively. These results are relatively like those of (Sahoo et al. 2020, Sarker et al. 2019, Wurts 2002). From the above discussion we might conclude that all the experimental ponds for present experiment were most suitable for silver carp fish fry culture.

Growth performance: Stocking density has the direct effect on growth rate and at the same it has adverse relationship with survival and production (Dambo and Rana 2008, El-Hawarry et al. 2018). After 60 days of culture period results of this study indicated that growth rate varied in different stocking densities and the highest specific growth rate found in T-1 $(14.13 \%)$ followed by T-2 (13.29\%) and T-3 (12.64\%) and that reveal, growth rate will find higher in low stocking densities which agree with the findings of (Apu et al. 2012, Costa et al. 2017). In lower stocking density fishes can easily consume feed and it might be gradually reduced with the increasing stocking densities. Significant differences in growth were found with increasing rearing time among the treatments where T-1 $(6.458 \pm 0.995 \mathrm{~g})$ performed the best and the minimum growth was observed in T-3 $(3.163 \pm 0.773 \mathrm{~g})$. The growth of silver carp fry in the current study is rather satisfactory in contrast to the result conducted somewhere else. Scientists reported in reba carp (Cirrhinus ariza) fingerlings, a maximum weight gain $2.54 \pm 0.16 \mathrm{~g}$ (low stocking density) and minimum weight gain $0.99 \pm 0.08 \mathrm{~g}$ (higher stocking density) after 8 weeks of rearing (Rahman et al., 2009). In another research work found that a final weight gain $4.69 \pm 0.17 \mathrm{~g}$ in 60 days that also among the lower site, relatively similar to the result of T-2 treatments (Hossain et al. 2013). 


\section{EFFECTS OF FISH STOCKING DENSITY ON GROWTH AND SURVIVAL OF H. MOLITRIX FRY}

SGR were recorded to be maximum for treatment T-1 and lowest for treatment T-3. The differences among the stocking densities of the specific growth rates of carp fry were not significant showed in the statistical analysis $(p \geq 0.05)$. One study reported a low range of specific growth rate was $3.21 \pm 0.001 \%$ per day that was comparatively low than the present study (Hossain 2012). The results of the present study were relatively similar with the result of (Rahman et al. 2009) who found that the SGR value of carp fry were $15.64 \pm 0.06 \%$ at the end of the experimental period with a stocking density of 0.8 million/ha. At the beginning the mean initials weights $(\mathrm{g})$ were same $(0.0016 \pm 0.00008 \mathrm{~g})$ in all the treatments and by the end of the study, the mean final weight of the harvested silver carp fry were $6.543 \pm 1.08,4.416 \pm 0.755$ and $3.163 \pm 0.873 \mathrm{~g}$ in T-1, T-2 and T-3, respectively. These are close agreement with the findings of (Rahman 2008).

Planktivorous fish need to be maintained optimum stocking density to obtain high production levels from a polyculture system (Rahman 2015). In this study survival rate of fingerlings was obtained higher in T-1 (85.76\%) followed by T-2 (79.11) and T3 (74.16\%). However, the results were better than the findings of (Hossain et al. 2013), who found that the survival rate of carp fry in three different treatments were 59.12, 55.05 and $63.11 \%$. Scientists found the survival rate of carp fry was comparatively high 95.53 in low density and 82.57 in high density for 60 days culture period (Samad et al. 2017). Another research showed survival rate 74.56 in low stocking density after 35 days rearing of fry (Samad et al. 2016).

This research focused on the effect of different stocking density on the growth performance, survival rate and production of silver carp fry $H$. molitrix. All the physicochemical factors of the ponds under the treatments of T-1, T-2 and T-3 were alike that found suitable for growth of carp fry during the study period. Here, lower stocking density proved better for carp fry rearing and provided better growth and production without affecting overall fish fry production. In treatment, T-1, stocked at 4000 fries/decimal showed maximum growth compare to treatment, T-2 (5000 fries/decimal) and T-3 (6000feies/decimal). In present, research, it found that the lower will be the production when stocking density will be higher. So, the current study indicated that, successful silver carp fry culture mainly depends upon the use of adequate stocking density.

\section{Literature Cited}

Malik, A., D. Kalhoro, S. Shah and I. Bux, 2014. The effect of different stocking densities on growth, production and survival rate of Pangas (Pangasius hypophthalmus) fish in cemented tanks. J. Interdiscip. Multidiscip. Res., 2014: 129-136.

Anderson, K., D. Chapman and C.A. Hayer, 2016. Assessment of dreissenid biodeposits as a potential food resource for invasive Asian carp. Bioinvasions Rec., 5(4): 251-257.

Apu, J., M. Rahman and P.H. Rashid, 2012. Effects of fish population densities on growth and production of fishes. Prog. Agric., 23: 63-73.

Attayde, J.L. and R. Menezes, 2008. Effects of fish biomass and planktivore type on plankton communities. J. Plank. Res., 30: 885-892.

Badran, M., 2001. Dissolved oxygen, chlorophyll a and nutrients: seasonal cycles in waters of the Gulf of Aquaba, Red Sea. Aquat. Ecol. Health. Manag., 4: 139-150. 
SK INJAMAMUL ISLAM et al.

Boyd, C.E., 2003. Guidelines for aquaculture effluent management at the farm-level. Aquaculture, 226(1-4): 101-112.

Chakraborty, B. and M.J.A. Mirza, 2007. Effect of stocking density on survival and growth of endangered bata, Labeo bata (Hamilton-Buchanan) in nursery ponds. Aquaculture, 265: $156-162$.

Costa, Â., R. Roubach, B.S.L. Dallago, G.W. Bueno, C. McManus and F.E.M. Bernal, 2017. Influence of stocking density on growth performance and welfare of juvenile tilapia (Oreochromis niloticus) in cages. Arq. Bras. Med. Vet. Zootec, 69(1): 243-251.

Dambo, W. and K. Rana, 2008. Effect of stocking density on growth and survival of Oreochromis niloticus (L.) fry in the hatchery. Aquac. Res., 24: 71-80.

El-Hawarry, W.N., R.A. Mohamed and S.A. Ibrahim, 2018. Collaborating effects of rearing density and oregano oil supplementation on growth, behavioral and stress response of Nile tilapia (Oreochromis niloticus). Egypt. J. Aquat. Res., 44(2): 173-178.

Enders, E.C. and D. Boisclair, 2016. Effects of environmental fluctuations on fish metabolism: Atlantic salmon Salmo salar as a case study. J. Fish Biol., 88(1): 344-358.

Gómez, J., E. Chuvieco and A. Sastre-Merlín, 2009. Monitoring transparency in inland water bodies using multispectral images. Int. J Remot. Sens., 30: 1567-1586.

Ferdousi, Z. and F. Haque, 2006. Effect of different stocking ratio of Pangasid catfish (Pangasius hypophthalmus) and Silver carp (Hypophthalmicthys molitrix) on better water quality maintenance in cat fish farming. Pakistan. J. Biol. Sci., 9: 1732-1737.

Hossain, I., S. Ahmed, M.S. Reza, M.Y. Hossain, M. Islam, J. Ara and R. Islam, 2013. Effects of organic fertilizer and supplementary feeds on growth performance of Silver carp (Hypophthalmichthys Molitrix) and Bata (Cirrhinus reba) fry in nursery ponds. Int. J. Res. Appl. Nat. Soc. Sci., 1: 117-124.

Hossain, M., M. Alam, M.R. Haque and M. Mehbub, 2013. Study on present status of carp-sis polyculture in Dinajpur district of Bangladesh. Bangladesh Res. Publ. J., 9: 123-130.

Hossain, M.Y., 2012. Effect of stocking density on survival, growth and production of Thai climbing perch (Anabas testudineus) under fed ponds. Sains Malay., 41: 1205-1210.

Hossain, M.Y., 2014. Effects of fry stocking densities on growth, survival rate and production of Hypophthalmichthys molitrix, Cyprinus carpio var. specularis and Labeo rohita in earthen ponds at Natore fish farm, Natore, Bangladesh. Int. J. Fish. Aquat. Stud., 2: 106112.

Huang, W.B. and T.S. Chiu, 2008. Effects of stocking density on survival, growth, size variation, and production of Tilapia fry. Aquac. Res., 28: 165-173.

Kohinoor, A.H.M., M.Z. Haque, M.G. Hussain and M.V. Gupta, 1994. Growth and survival rate of Thai punti, Puntius gonionotus (Bleeker) spawn in nursery ponds at different stocking densities. J. Asiatic Soc. Bangladesh. Sci., 20: 65-72.

Kohinoor, A.H.M., M. Rahman, J. Rashid and M. Islam, 2018. Production potentials of pabda (Ompok pabda, Hamilton) in semi-intensive management under different stocking densities. Bangladesh J. Fish., 30(1): 37-45.

Neubauer, P. and K.H. Andersen, 2019. Thermal performance of fish is explained by an interplay between physiology, behaviour and ecology. Conserv. Physiol., 7(1): coz025.

Priyadarshini, M., J.B.G. Manissery and K. Perar, 2011. Influence of feed, manure and their combination on the growth of Cyprinus carpio (L.) fry and fingerlings. Turk. J. Fish. Aquat. Sci., 11: 577-586. 
EFFECTS OF FISH STOCKING DENSITY ON GROWTH AND SURVIVAL OF H. MOLITRIX FRY

Rahman, M. and K. Marimuthu, 2010. Effect of different stocking density on growth, survival and production of endangered native fish climbing perch (Anabas testudineus, Bloch) fingerlings in nursery ponds. Adv. Environ. Biol., 4: 178-186.

Rahman, M., M. Zaher and K.M. Azimuddin, 2008. Evaluation of growth, survival, and production of an endangered fish, Labeo gonius (Hamilton) fingerlings in earthen nursery ponds. J. Appl. Aquac., 20: 62-78.

Rahman, M., M. Zaher and K.M. Azimuddin, 2009. Development of fingerling production techniques in nursery ponds for the critically endangered Reba carp, Cirrhinus ariza (Hamilton, 1807). Turk. J. Fish. Aquat. Sci., 9: 165-172.

Rahman, M.M., 2015. Role of common carp (Cyprinus carpio) in aquaculture production systems. Front Life Sci, 8(4): 399-410.

Rounds, S.A., F.D. Wilde and G.F. Ritz, 2006. Chapter A6. Section 6.2. Dissolved oxygen (09-A6.2). Retrieved from reston, VA: http://pubs.er.usgs.gov/publication/twri09A6.2

Sahoo, P.R., P. Das, S. Nanda, K. Mohanta, B. Sahu, G. Kund and S.Tanuja, 2020. Influence of water alkalinity in production of stunted fingerlings of Catla catla (Hamilton). Int. J. Curr. Microbiol. Appl. Sci., ??: 1784-1791.

Samad, M., P. Chowdhury, S. Chatterjee, M. Rahman and S. Barman, 2017. Growth response of threatened Labeo calbasu (Hamilton) fingerling based on stocking density in ponds. Int. J. Exp. Agric., 7(1):1-8.

Samad, M., A. Khatun, M.S. Reza, M. Asrafuzzaman and M. Ferdaushy, 2016. Effects of stocking density on growth, survival and production of mirror carp (Cyprinus carpio var. specularis) spawn in nursery pond. Asian J. Med. Biol. Res., 2: 429-435.

Sarker, S., S. Mahmud, R. Sultana, R. Biswas, P.P. Sarkar, M.A. Munayem, M.O. Faruque and F.Z. Evamoni, 2019. Quality assessment of surface and drinking water of Nakla Paurosova, Sherpur, Bangladesh. Adv Microbiol., 9(8): 703-727.

Shoko, A.P., S.M. Limbu, H.D.J. Mrosso and Y.D. Mgaya, 2014. A comparison of diurnal dynamics of water quality parameters in Nile tilapia (Oreochromis niloticus, Linnaeus, 1758) monoculture and polyculture with African sharp tooth catfish (Clarias gariepinus, Burchell, 1822) in earthen ponds. Int. Aquac. Res., 6(1): 56.

Stepien, C.A., M.R. Snyder and A.E. Elz, 2019. Invasion genetics of the silver carp Hypophthalmichthys molitrix across North America: differentiation of fronts, introgression, and eDNA metabarcode detection. PLoS One, 14(3): e0203012.

Wurts, W., 2002. Alkalinity and hardness in production ponds. World Aqua., 33: 16-17.

Xu, H., S. Liu, Q. Xie, B. Hong, W. Zhou, Y. Zhang and T. Li, 2016. Seasonal variation of dissolved oxygen in Sanya Bay. Aquat. Ecosyst. Health., 19(3): 276-285. 